\title{
The Analysis of Students' Ability of Decimal Numeral Multiplication of the Fifth Grade Students
}

\author{
Suwariyasa, Made \\ Ganesha University of Education \\ madesuwariyasa@gmail.com
}

\begin{abstract}
This study aimed to (1) describing Learning multiplication of decimal fractions in V grade,(2) The students' ability in completing the multiplication of decimal fractions, (3) The constraints which were faced by students in completing the multiplication of decimal fractions and the solutions to overcome those obstacles. The type of this study was descriptive quantitative and qualitative research. The subjects of this study were the fifth grade students of SD Negeri 2 Penarukan, consisted of 20 students and teachers in V class. The object of this study were (1) Learning multiplication decimal fraction in V grade, (2) The students' ability in completing the multiplication of decimal fractions, (3) The constraints which were faced by students in completing the multiplication of decimal fractions and the solutions to overcome those obstacles. The observation, test, interview, and documentation were used to collect the data. The data were analyzed using descriptive quantitative and qualitative approach. The results showed (1) Learning multiplication decimal fractions was categorized good with a value of 84 , (2) the average test results in classical 59.9 with low category with the highest indicators is to solve everyday problems which involves multiplication of various fractions $55.25 \%$ and the lowest indicator is determining the results of multiplication operations of various fractional $88.5 \%$, (3) The constraints faced by students are: forget the concept of decimal fractions multiplication operations, forget to put coma at the end of the answer and students are still confusein completing the essay task. The solution to overcome those constraints aregiving students a lot of exercises regarding the multiplication of decimal fractions. So that students are better trained and familiar with the particular multiplication exercises.
\end{abstract}

Keywords: math, ability, multiplication of decimal fraction

\section{Introduction}

Mathematics is one of the subjects given at every level of education, and plays a role in improving the quality of human resources. Mathematics is a basic knowledge that should be possessed by the students. Moreover, mathematics is one of the subjects that is considered having an important role in shaping the quality of students. This is caused by the importance of mathematics education that cannot be separated from its role in all aspects of both everyday life and in another scope of science. Mathematics is also useful to support the success of students learning in a higher level of education.

One of learning objectives of mathematics is to develop problem solving ability. It shows that problem solving is one of very important abilities in mathematics learning. According to Hudojo (in Aisyah, 2007:5-3), "Problem solving basically is a process done by someone to solve problems until the problem does not exist." The learning will be more directional if it starts with the problem that must be solved by the students. Situations that require the student to be able to solve the problem will encourage the students to develop thinking ability maximally (Aiyah, 2007:5-3).

Mathematics learning in basic education means "provide the students with ability to think logically, analytically, systematically, critically, and creatively" (Japa and Suarjana, 2012:3), as well as the ability to work cooperatively. This ability is a competency that is required by the students to possess the ability to acquire, manage, and use information to survive in a situation that always changes uncertainly and competitively.

In mathematics learning in elementary schools, especially in class $\mathrm{V}$, one of the materials learned is a decimal fraction. Decimal fraction is a fraction that has a special denominator, namely ten, a hundred, a thousand, and so on. To learn the concept of decimal 
fraction, it can be started with the concept of fractional tithe and followed with fractional centesimal. An understanding of the writing concept of decimal fractions is very important for students in learning the material of decimal fractions. Decimal fraction number is a number generated from the results of division of a number with number 10 and its multiple. An operation of decimal fraction multiplication may be preceded by changing the decimal fraction into a common fraction (Japa and Suarjana, 2013). We can see a pattern related to the position of a comma on the result of the multiplication. Multiplication of decimal fractions is as easy as a whole number multiplication.

Based on an observation that was conducted at SD Negeri 2 Penarukan, the students confused in answering mathematics questions with material of decimal fraction multiplication. In answering the questions of decimal fraction multiplication, most of the students put coma on wrong position, as well as wrong in multiplying. This is because the students did not understand the questions.

Besides, the learning method used was still conventional. The learning process was dominated by assignment and exercise so that in a relatively short time, the teachers could complete the teaching material. This was because the teacher needed to finish the curriculum target. That was a factor which made the students not interested in math. In addition, based on interviews with the fifth grade teachers, the teachers said that the students always complain and tend to be lazy to answer the questions given. Students also felt poorly practiced in answering the question about multiplication of decimal fractions. That was changing the decimal fraction into the common fraction. In addition, there were students who put a comma on decimal precision in the wrong position.

Furthermore, It was obtained data about the mathematics learning achievement of the fifth grade students in the first semester of academic year 2014/2015 at SD Negeri 2 Penarukan based on the value of report cards cited January 6 , the average score in mathematics 60 , while the minimal value of completeness of mathematics is 68 . The low students' mathematics achievement could also be caused by the learning process that was delivered by the teachers was monotonous and was not creative.

Based on the above explanation, it was necessary to analyze the students' ability in answering mathematics questions, especially in multiplication of decimal fractions. So that's why it was conducted a research entitled "The analysis of students' ability in answering multiplication of decimal fraction of the fifth grade of SD Negeri 2 Penarukan, Buleleng district, Buleleng regency in academic year 2015/2016".

This study formulated (1) multiplication learning of decimal fraction of the fifth grade at SD Negeri 2 Penarukan, (2) the students' ability in answering multiplication of decimal fraction of the fifth grade at SD Negeri 2 Penarukan, (3) the problems faced by the students in answering multiplication of decimal fraction at SD Negeri 2 Penarukan and solutions to solve the problems.

This study aimed to describe (1) multiplication learning of decimal fraction of the fifth grade at SD Negeri 2 Penarukan, (2) the students' ability in answering multiplication of decimal fraction of the fifth grade at SD Negeri 2 Penarukan, (3) the problems faced by the students in answering multiplication of decimal fraction at SD Negeri 2 Penarukan and solutions to solve the problems.

\section{Research Methods}

This research is a descriptive study that explained or presented data from the study. The data in this study were a qualitative and quantitative data. The data were analyzed using qualitative and quantitative descriptive analysis.

The subjects of this study were 20 students of class V of SD Negeri 2 Penarukan, Buleleng district, Buleleng regency in the academic year 2015/2016. This study only took 
one class as the subject of the study. This is called saturated sampling technique. Sugiyono (2009) states "saturated sampling is a sampling technique when all members of the population are used as the sample".

The data that were needed in this study was how multiplication learning of decimal fraction is, the ability of fifth grade students at SD Negeri 2 Penarukan, Buleleng district, Buleleng regency in academic year 2015/2016 in answering multiplication of decimal fraction and problems that affected the students' ability as well as solutions in answering multiplication of decimal fractions.

Methods of collecting data used in this study were observation method, test method (essay test), interview method and documentation method. The instruments used to collect the data were observation sheets, test, interview guidelines and documentation guidelines.

\section{Finding}

\section{Findings and Discussion}

Based on the observation that was conducted to a teacher in multiplication learning process of decimal fraction, the teacher taught the students about multiplication of decimal fraction according to the observation guidelines that had been prepared. In the observation guidelines that were arranged, there were some aspects that were categorized as pre-learning, opening the learning, while activity, and closing the learning. But there were some components that had not been implemented by the teacher when implementing multiplication learning of decimal fractions.

While the observation, the teacher was not using teaching media. The teacher only used the discussion method to finish the questions given. The students were divided into 2 groups that consisted of their groupmate. The teachers guided the discussions with the groups. After finishing the questions given by the teacher, one of representatives of the groups was expected to read the results of the discussion. After finishing the discussion, the teacher discussed the questions that were difficult with the students.

At the end of the lesson, the teacher gave reflection to the student and asked the students about the material that was not understood yet by the students about the material that had been learned. That was a multiplication of decimal fractions. The teacher also gave homework for the students. Overall the teacher taught according to the time allotment, so the students could take their break time on time.

After processing the data from the observation of multiplication learning of decimal fraction in class $\mathrm{V}$, it was found score 84 . After converting into table 3.6, the percentage was categorized as good. The teacher needed to improve the multiplication learning of decimal fraction in order to get better achievement.

The students' ability in answering the multiplication of decimal fraction at SD Negeri 2 Penarukan was measured by two indicators. After processing the score, the test result obtained by the students varied from one student to the other students, from high categorized score to the very low category. From the processing score, two students got high categorized score, nine students got medium categorized score, three students got a low categorized score and six students got very low categorized score. For the average score of the student test results in answering the multiplication of decimal fraction of the fifth grade at SD Negeri 2 Penarukan was classically obtained a value of 59.9 that was categorized as sufficient.

The following are the results of students' ability test in answering multiplication of decimal fraction of the fifth grade at SD Negeri 2 Penarukan in the form of a frequency distribution as presented in Table 1. 
Table 1. Calculation of test results mean data solving multiplication fractional decimal

\begin{tabular}{cccl}
\hline Interval Score & $\mathbf{f}$ (frequency) & $\mathbf{X}$ (Median) & $\mathbf{F x}$ \\
\hline $80-93$ & 2 & 86.5 & 17 \\
\hline $66-79$ & 9 & 72.5 & 65 \\
\hline $52-65$ & 4 & 58.5 & 23 \\
\hline $38-51$ & 1 & 44.5 & 44 \\
\hline $24-37$ & 2 & 30.5 & 61 \\
\hline $10-23$ & 2 & 16.5 & 33 \\
\hline Total: & $\mathrm{N}$ & - & $\sum \mathrm{f}$ \\
\hline
\end{tabular}

Based on Table 1 shows that the calculation of the mean data of the test result of decimal fraction multiplication, it can be seen that the number of students between the range of scores 80-93 is 2 students with the median of each interval 86.5 and frequency multiplication result of the median of each interval is 173 . The number of students who got a range of values 66-79 is 9 students with the median of each interval is 72.5 and frequency multiplication result of the median of each interval is 652.5. The number of students who have a range of values 52-65 is four students, the median of each interval is 58.5 and frequency multiplication result of the median of each interval is 234 . The number of students who got a range of values from 38-51 is one person with the median of each interval is 44.5 and frequency multiplication result of the median of each interval is 44.5 . The number of students who got a range of values of 24-37 is 2 students with the median of each interval is 30.5 and frequency multiplication result of the median of each interval is 61 . The number of students who got a range of values from $10-23$ is 2 people with the median of each interval is 16.5 and frequency multiplication result of the median of each interval is 33 . The total number of students is 20 students and the number of the whole frequencies is 1198. So the students' ability in answering multiplication of decimal fraction is $59.9 \%$. The Calculation of test result means of answering multiplication of decimal fraction, It was obtained the test results in the classical with an average of 59.9 that is categorized as sufficient. The fifth grade students had been able to answer multiplication of decimal fraction that were given, but it still needs to be improved.

Of the two indicators on the multiplication questions of decimal fraction that were given, the students' ability varied between one question indicator with another question indicator. The following is the date table of students test result based on indicators, as presented in table 2.

Table 2. The students' ability in answering the multiplication of decimal fraction based on indicator

\begin{tabular}{clcc}
\hline $\begin{array}{c}\text { No. of } \\
\text { Item }\end{array}$ & \multicolumn{1}{c}{ Indicator } & $\begin{array}{c}\text { Percentage of Category } \\
\text { score }\end{array}$ & High \\
\hline 1 & $\begin{array}{l}\text { Answering the result of } \\
\text { multiplication in form of a } \\
\text { fraction. }\end{array}$ & $88.5 \%$ & \\
\hline $2,3,4,5$ & $\begin{array}{l}\text { Solving daily problems about } \\
\text { multiplication in form of a } \\
\text { fraction. }\end{array}$ & $55.25 \%$ & Low \\
\hline
\end{tabular}

The Students' ability to solve problems varied from one student to the other students and the students' problem in answering the question was also different for each indicator.

In terms of "determining the result of various forms of fractional multiplication", the test result obtained was $88.5 \%$, this showed that $88.5 \%$ of the students were able to answer the questions about the results of answering multiplication of various fractions contained on questions that had been given. Based on observations and interviews, other students had not been able to understand multiplication of decimal fraction that were given so that the student 
is difficult in answering the question and the students had not memorized the multiplication.

In "solving daily problems about multiplication of various forms of fraction", the test result was $55.25 \%$, which was categorized low. This category indicated $55.25 \%$ of the students had been able to answer the question that involved daily problem about multiplication of various fractions on each question given. The other students had not been able to answer the questions, because students did not understand what was meant by the questions. Based on the interview, students' difficulties in answering multiplication of decimal fraction if the questions were in the form of stories. The students did not understand about the questions in the form of stories and they usually forgot to put a comma at the end of the answer, as well as they did not memorize the multiplication.

The students' ability in answering multiplication questions of decimal fraction of class V at SD Negeri 2 Penarukan was the first indicator that was categorized as high, while the second indicator was categorized as low. This showed that there were still indicators of the questions that could not be achieved yet by the fifth grade students that were caused by many things that has been described as follows.

The students' ability in answering the multiplication of decimal fraction based on Table 3 the students' ability in answering the multiplication of decimal fractions based on cognitive domain.

Table 3. The students' ability in answering the multiplication of decimal fraction based on cognitive domain

\begin{tabular}{cccccc}
\hline $\begin{array}{c}\text { Cognitive } \\
\text { Domain }\end{array}$ & & \multicolumn{3}{c}{ Number of the Students Number of the Student } \\
$(\%)$
\end{tabular}

Question domain C2, 15\% of the students had not been able to answer C2 questions and $85 \%$ of the students had been able to answer C2 questions. It showed that 17 students were already able to understand how to answer the questions given while 3 students had not been able to answer the questions and did not understand how to answer. Based on the interview, the students did not understand the question and did not memorize multiplication.

Question domain C3, 35\% of students were already able to answer C3 questions and $65 \%$ of the students were already able to answer C3 questions. It showed 13 students were already able to apply or implement concepts of multiplication of decimal fraction given, while 7 students had not been able to implement or apply the concepts of multiplication of decimal fractions.

Question domain C4, 25\% of the students had not been able to answer the $\mathrm{C} 4$ questions and $75 \%$ of the students were already able to answer $\mathrm{C} 4$ questions. This showed that 5 students had not been able to analyze multiplication of decimal fraction given, while 15 students were already able to analyze the questions given. Based on the interview conducted, the students did not understand what the question in the form of story meant because in the learning process, the students did not understand and feel shy for asking.

Question domain C5, 25\% of students had not been able to answer C5 questions and $75 \%$ of the students were already able to answer C5 questions. This showed that 5 students had not been able to synthesize the questions given, while 15 students were already able to synthesize the questions given. Based on the interview, the students had not been able to 
understand about the question given and they were embarrassed to ask the questions that they did not understand.

Question domain C6, 40\% of the students had not been able to answer the C6 questions and $60 \%$ of the students were already able to answer C6 questions. It showed 8 students had not been able to evaluate the questions given, while 12 students have been able to evaluate the questions given because in C6 questions, the students were able to answer the questions as well as well as provide a reason of the question answers.

\section{Discussion}

Thus, it could be concluded that there were questions that could be answered yet by the students based on the indicator or cognitive domain. The indicator "Solving daily problems involved the multiplication of various fractions" was the indicator with the lowest student's ability and the question domain C6 (evaluation) was the domain with the lowest students' ability. The students' average test results classically based the Table 4.1, the calculation of the mean data of answering the multiplication of decimal fraction obtained a value of 59.9 that was categorized sufficient.

This showed that the students' ability in answering the multiplication of decimal fractions of the fifth grade students of SD Negeri 2 Penarukan needed to be improved, so the students' ability in answering the multiplication of decimal fractions was increasing.

In the learning process that had been done by the teacher with the materials of multiplication of decimal fractions, that's the way the teacher taught was categorized as good with a value of 84 , because the teacher had followed the stages of the lesson plan (RPP) by using the question and answer method. In line with the opinion of Ruminiati (2008:2-4-2), "Question and answer method is a method that aims to attract the students' attention to be more focused on the learning". Based on this method, the students were more profound understanding. If the students did not concentrate, the teacher could ask questions as an effort to raise the concentration of the students, so they became more concentrated because they were forced to answer the questions given.

The students' ability in answering the questions was different from one student to the other students and the students' problem in answering the questions was also different from each indicator of the questions. In answering multiplication of various fractions consisting of one question. The test results were obtained for the first indicator was $88.5 \%$, this showed that $88.5 \%$ of the students were able to answer the questions about multiplication of various fractions in the questions given. Based on observation and interview, other students had not been able to understand multiplication of decimal fractions that were given, so that the students were hard to answer and the students had not memorized the multiplication.

In solving daily problems involving multiplication of various forms of fractions which consisted of four questions. The test results obtained were $55.25 \%$, which was included in the low category. This category indicated that $55.25 \%$ of the students had been able to solve problems about daily problems involving multiplication of various forms of fractions contained on questions that have been given. The other students had not been able to solve the question, because the students did not understand what the question in the story was about. Based on the interview, students had difficulties in solving multiplication about decimal fraction if the question was in the form of the story. Students did not understand what was meant by the problems in a story and students often forgot to put a comma at the end of the answer and students are less familiar with multiplication tables.

It could be concluded that the ability of students in solving multiplication of decimal fractions in the fifth grade of SD 2 Penarukan was the first indicator in which was categorized in the high category, while the second indicator was categorized low. This showed that there was still a matter of indicators that could not be solved by students of class $\mathrm{V}$ which were 
caused by many things such as that had been described before.

From the results of interviews with teachers for the fifth grade, it had been obtained information that the problems faced by the students while completing multiplication in the form of decimal fractions was that some students were still not proficient with multiplication so that when doing multiplication especially in multiplication of decimal fractions students required more time. And when working on the problems, especially when working about story problems a lot of students were confused on how to do it. According to fifth grade teacher, to overcome these, students need a lot of exercise with the multiplication of decimal fractions problems so that students were trained and familiar with the multiplication especially exercises involving story.

Based on interviews with some of the fifth grade students, students still felt confused in working with multiplication about decimal fractions and students had not memorized the multiplication table so that in solving the problems some students could answer the questions wrongly.

The same thing was also expressed by teachers that taught the fifth grade, the fifth grade students were often confused when working on the problems, especially on the problems involving story and the students were often forgotten the concept of multiplication, especially about the multiplication of decimal fractions. After conducting interviews with the teacher, solution to overcome this problem was to give plenty of exercise, especially problems involving story about the multiplication of decimal fractions so that students would often practice.

On learning process about the multiplication of decimal fractions problems that were faced by students when completing problems about multiplication of decimal fractions were some students were not proficient with multiplication, so that when doing multiplication problem especially multiplication of decimal fractions students required more time. And when working on the problems, especially problems involving stories a lot of students were confused how to do it.

The solution to solve these problems were for students to do a lot of exercise about the multiplication of decimal fractions problems so that students were trained and familiar with the particular multiplication especially problems which involve the story.

Another problem faced by students was that students forgot to put a comma at the end of the answer. In line with the opinion of Japa and Suarjana (2013:138), namely: As with addition and subtraction of decimal fractions, the decimal multiplication operation also could be preceded by transforming decimal fraction into a normal fraction. After that, pattern related to the position of a comma would be seen on the result of the multiplication.

Besides the above problems, problem faced by students in solving multiplication of decimal fractions was students feel confusion in the problem involving story because students did not understand about the story and students often forgot to put a comma at the end of the answer. According to Nolting (2011: 117) the students misunderstood the question was because of: Mistakes in understanding the problems were mistakes that had been made because the way of understanding the problem were done in a special way, such as not completing the problem to the last step or not answering a question fully and only completed one phase of the two phases which caused some students to lose points.

Solutions to solve the problems faced by students in completing the multiplication of decimal fractions were by giving some examples of the questions during the learning process and doing exercise to solve problems especially problems about multiplication of decimal fractions more often. Assign homework, so that students not only practice in schools, but also practice at home. In providing exercise questions which would be given to students, it should be linked to daily life of students, which would make it easier to be understood and would not make them confused in solving the problems which were given especially about the material 
of multiplication of decimal fractions. Besides that, in teaching, especially teaching multiplication of decimal fractions, teachers should use learning media to make students easier to understand and remember the material which was being taught.

\section{Conclusion}

Learning multiplication of decimal fractions as a whole had been categorized in good categories with a score of 84 . When learning the multiplication of decimal fractions, teachers had guided students when doing exercises provided by the teacher. Teachers always implement the learning process in accordance with the time, so it did not reduce the rest time of the students. At the end of the lesson the teacher always gave homework to be done individually.

The ability of the student in completing the multiplication of decimal fractions of the fifth grade of SD Negeri 2 Penarukan, in overall, it still needs to be improved because they are classified as sufficient. The highest score obtained by the students was 80 while the lowest score obtained by the students was 10 . Based on that, it was then gained an average of 59.9 for the test results which could be classified as sufficient. Of the 20 students, nine students who received scores below the average were $44 \%$, while students who received grades above the average were 11 people were $75.63 \%$. Judging from the highest indicator in the student's ability to complete the multiplication of decimal fractions was indicators to determine the results of operations of multiplication of various forms of fractions with a percentage of $88.5 \%$, while the lowest indicator was an indicator to solve daily problems involving multiplication of various forms of fractions with a percentage of 55, $25 \%$.

Problems faced by students in solving multiplication of decimal fraction for fifth grade from results of interviews which had been conducted with teachers and some students were that students were not familiar with particular multiplication especially multiplication of decimal fractions. Students felt confused when answering problems involving story and often forgot to put a comma at the end of the answer. According to the fifth grade teacher, to solve these problems, students need to do a lot of exercise on solving problem about the multiplication of decimal fractions so that students were trained and familiar with the particular multiplication especially problems involving story.

Based on the results of the research, several suggestions could be put as follows. For School, it need to be used as consideration in giving multiplication of decimal fractions problems so it could improve the quality of learning activities. For the teachers, they need to be more creative, innovative and active in preparing and choosing learning media and learning methods which could train students in completing activities of doing multiplication of decimal fractions problems so that students could understand and remember the material they had learned more. For other researchers, it may be used as reference to do research on students' ability in solving multiplication of decimal fractions in elementary schools using different methods and goals.

\section{References}

Aisyah. Nyimas dkk. (2007). Pengembangan Pembelajaran Matematika SD. (The Development of Elementary School's Math Subject Matter). Jakarta: Depdiknas.

Hudojo, Herman. (2001). Pengembangan Kurikulum dan Pembelajaran Matematika. (The Development of Curriculum and Mathemathics Subject Matter). Malang: Malang State University.

Japa, I Gusti Ngurah dan I Made Suarjana. (2012). Pembelajaran Matematika SD. (Math Learning fo Elementary Schools). Singaraja: Ganesha University of Education. 
Japa, I Gusti Ngurah dan I Made Suarjana. (2013). Pendidikan Matematik II. (Mathematics Learning ( $2^{\text {nd }}$ Edition)). Singaraja: Ganesha University of Education.

Nolting, Paul D. (2012). Math Study Skill Workbook Fourth Edition. Academik: Succsess Press.

Ruminiati. (2008). Pengembangan Pendidikan Kewarganegaraan SD. (The Development of Civics in Elementary Schools). Jakarta: Depdiknas.

Sugiyono. (2009). Metode Penelitian Kuantitatif kualitatif dan $R \& D$. (The Methods of Quantitative, Qualitative and R\&D). Bandung: Alfabeta 